tion with Champagne .3, whereas Paris metropolitan area .36 , by its indentation and lighter type, is clearly a subdivision of the ile-de-France. At the same time, the columnar arrangement of the geographical units makes the tables easier to use than the cramped paragraph arrangement of the fourteenth edition. In fact, the type has been reset throughout and the excessive differences of size, weight, and style of type faces have been eliminated.

In addition to typography, the terminology has been gone over thoroughly and brought up to date. Not only has the spelling been returned almost to normal, but innumerable outdated words and phrases have been replaced by current nomenclature. For example, changes have been made in the headings of the major classes: "Language" replaces "Filology," "Technology" is in place of "Useful arts Applied science," and "The Arts" for "Fine arts Recreation." Throughout the schedules the editors have shown sound judgment in selecting terms that are in general use. More important is the addition of extensive annotations. These include definitions and scope notes, inclusion notes, instruction notes, and cross references.

For a related series of numbers, centered headings have been introduced, with notes covering the whole sequence, which serve as a substitute for a comprehensive heading and obviate the need to repeat the notes under each individual number. Space prevents a more detailed discussion of the annotations here but the editor, in his introduction, does an excellent job of exposition.

Because the major portion of these annotations is entirely new, and because the new typographical arrangement is so generous with space, the sixteenth DC shows an overall increase of 512 pages, despite the fact that the actual number of entries is cut by 13,436 , or almost half of those in the fourteenth DC. As a result, the work has been divided into two volumes; any inconvenience incurred by this separation is of minor importance when compared with the incalculable improvements of the new format. Some may even prefer to work with two separate volumes.

The second volume consists primarily of the Relative Index, which has approximately the same number of entries as the index to the fourteenth edition but, like their corre- sponding tables, the entries have been thoroughly revised and reworded. The material following the index, however, is quite different from the fourteenth DC. Particularly noteworthy is the reprinting of the special author table for Shakespeare (one wonders why it was omitted previously) and the elimination of both the Table for Systematic Botany (now printed in very abridged form in the Botany schedule) and the Supplementary Tables. The Table of Form Divisions, salvaged and sensibly expanded, has been placed immediately preceding the classification tables, a far more convenient position. Less understandable is the retention of the list of topics which may be divided geographically. Since instructions on division are given in the tables themselves for each of the 322 places, their listing in straight numerical order in the second volume would seem to be of limited value.

In conclusion, one can say that the sixteenth DC shows a tremendous improvement in terms both of structural balance and of facility to the user. Although there is no complete solution to the basic conflict between advancing knowledge and a predetermined scheme of classification, the editors have effected a compromise that probablv will be welcomed in libraries committed to the Dewey Decimal Classification. Libraries which have found DC unsatisfactory in its basic principles have shifted to other systems.-Alison Smith, Metropolitan Museum of Art Library, New York.

\section{Studies in Germanics}

Germanistische Studien. By Arno Schirokauer. Selections and introduction by Fritz Strich. Hamburg: Ernst Hauswedell \& Co., 1957. $451 \mathrm{p}$.

From Arno Shirokauer's numerous studies in Germanics this valuable volume contains twelve which he published between 1924, four years after his first, and 1954, the year of his death. In its chronological arrangement the selection is representative not only of Schirokauer's course of development, but of the scope and dimensions of his scholarship. The first reprinted here is his early

COLLEGE AND RESEARCH LIBRARIES 
treatise on Expressionism in German poetry; and to Expressionism he returned with his last essay on Ernst Stadler. The emphasis of Schirokauer's research is on the German language and literature of the old period, the Middle Ages, and the dawn of modern times-his pioneering investigations and interpretations ranging from the second "Merseburger Zauberspruch" to Otfrid von Weissenburg; Hartmann von Aue's legend of Poor Henry; Aesop's role in the literature of the Middle Ages; the history of the word "Herr;" the influence of the printing press on the development of a common German language; and in particular a scrutinizing examination of the "dark, uncertain lawless, and problematical period" (Strich) of the fourteenth and fifteenth centuries, i.e., the formation of Early New High-German leading from the decline of classical medieval accomplishment on to Luther. But there are, further, outstanding essays on the change of the significance of the novel; late Romanticism in the Grimm dictionary; and new problems of German philology of the most recent past. All of these studies are only the gems from the author's immense wealth. (Including radio broadcasts and book reviews, the bibliography of his publications appended to this volume lists 149 items.)

Schirokauer is everywhere in pursuit of a living cultural totality. Above all, he is a philologist who, with a remarkable degree of sensibility, enters upon the form, sound, syntax, and rhythm of the living idiom as the literary scholar's primary objective. At the same time we are in every instance presented with a carefully drawn tableau of a many-faceted historical-philosophical-social unity. His writing is distinguished by this combination of the philological and aesthetic with a sense for the interrelation and mutual fertilization of formative factors in cultural history, as it is reflected in, and produces, expression. His encyclopedic knowledge of fact, his precision of detail and exhaustive accuracy are never statistical. Rather, they are animated by the flow of development as which Schirokauer saw the essence of his subject matter. This is also the mark of his style - a dynamic expressiveness in the refinement and clarity of his own vivid form. It rises itself to literary accomplishment, the perceptive and creative scholar-critic's art at its best.

Fritz Strich, as Schirokauer's former teacher, was particularly competent to make the arrangement of this book, and to furnish an introduction in appreciation of the author's personality and achievement.-Gerhard Baumgaertel, University of Pennsylvania.

\section{Classified Advertisements}

Rate: $\$ 1$ per line; 3-line minimum. Closes twentieth of month preceding date of issue.

Colonial Book Service-Specialists in supplying the out-of-print books as listed in all library indices (Granger Poetry; Essay and General Literature; Shaw; Standard; Fiction; Biography; Lamont; Speech; etc.) Want lists invited. 23 East $4^{\text {th }}$ St., New York 3, N. Y.
We want (sob) to be on your mailing list, IF you can supply the library for a newly established college. Send your lists, catalogs, salesmen, etc., to: Janet Polacheck, Librarian, Tri-County College, c/o Hoyt Public Library, Saginaw, Michigan. 